\title{
A Study on Bovine Mastitis Related Oxidative Stress along with Therapeutic Regimen
}

\author{
Anshuman Mahapatra ${ }^{1}$, Sumitra Panigrahi ${ }^{2}$, Ramesh C. Patra ${ }^{3}$, \\ Mangalika Rout ${ }^{4}$ and Subha Ganguly ${ }^{5}$.
}

${ }^{1}$ Department of Veterinary Clinical Medicine, Orissa University of Agriculture and

Technology, Bhubaneswar - 751003, Odisha, India

${ }^{2}$ Department of Veterinary Public Health and Epidemiology, College of Veterinary Sciences and Animal Husbandry, Lala Lajpat Rai University of Veterinary and Animal Sciences, Hisar - 125004, Haryana, India

${ }^{3}$ College of Veterinary Sciences and Animal Husbandry, Orissa University of Agriculture and Technology, Bhubaneswar - 751003, Odisha, India

${ }^{4}$ Department of Animal Breeding and Genetics, Orissa University of Agriculture and

Technology, Bhubaneswar - 751003, Odisha, India

${ }^{5}$ Department of Veterinary Microbiology, Arawali Veterinary College (Affiliated to Rajasthan

University of Veterinary and Animal Sciences, Bikaner), N.H. - 52 Jaipur Road, V.P.O. Bajor,

$$
\text { Sikar-332001, Rajasthan, India }
$$

*Corresponding author

\section{A B S T R A C T}

\begin{tabular}{|l|}
\hline Ke y w o r d s \\
$\begin{array}{l}\text { Dairy cattle, } \\
\text { Mastitis, Oxidative } \\
\text { stress, Therapy }\end{array}$ \\
\hline Article Info \\
\hline $\begin{array}{l}\text { Accepted: } \\
\text { 04 December } 2017 \\
\text { Available Online: } \\
\text { 10 January } 2018\end{array}$ \\
\hline
\end{tabular}

Dairy industry is gradually emerging as a major player in the field of agricultural economy. Consequently the management scene and concomitant disease control regimen have become more important for production and economic reasons. Despite innovations in various therapeutic regimens and improved management practices, mastitis unfortunately has remained ever green. Mastitis is a multi-etiological complex disease, which is defined as inflammation of parenchyma of mammary glands and is characterized by physical, chemical and usually bacteriological changes in milk and pathological changes in glandular tissues (Radostits et al., 2010). Mastitis may be classified as clinical and subclinical. In contrast to visible changes in the clinical form of mastitis, there is absence of gross abnormalities in the milk or udder in case of subclinical mastitis. The average incidence of clinical mastitis varies from 10 to $20 \%$ in most of the herds and the prevalence of intra mammary infection is around $50 \%$ of quarters (Radostits et al., 2007). Further, the subclinical mastitis (SCM) is 3- 4 times more prevalent than clinical mastitis (Bhanderi and Garg, 2012). Therefore, milk production loss is more in subclinical mastitis as compared to clinical form because of increase in undesirable milk components like proteolytic enzymes (Pyorala, 2003), salts and also increase in somatic cell count, thereby resulting in decrease in the desirable components such as protein, milk fat and lactose. The present study was conducted for investigating the alterations in the activities of erythrocyte glutathione peroxidase (GSH-Px) and its functional components in cows with subclinical mastitis and normal cows of Odisha along with the therapeutic efficacy for antioxidants along with antibiotics on restoration of changes in oxidative stress indices. 


\section{Introduction}

Both clinical and subclinical, remains a problem in dairy herds and prevalence rates in many countries. MCMT, somatic cell count and electrical conductivity of milk are most frequently used tests in dairy cattle to diagnose clinical and subclinical mastitis. The specificity of the oxidative stress and its relation to mastitis and other diseases is a complex phenomenon. One of the symptoms of mastitis is an increased NO level and a reduced content of ascorbic acid in the blood serum of animals (Sordillo et al., 2009; Jozwik et al., 2012b). Oxidative stress is commonly defined as an imbalance between oxidants and reductants (antioxidants) at the cellular or individual level. The involvement of oxidative stress in mastitis is further substantiated by data from experimental mastitis induced either by intramammary infusion of E. coli bacteria (Blum et al., 2000; Weiss et al., 2004; Wakchaure et al., 2015) or E. coli or staphylococcal endotoxin (Blum et al., 2000; Bouchard et al., 1999; Komine et al., 2004). Antibacterial activity of neutrophils is interceded, in part, through reactive oxygen species (ROS) (Rinaldi et al., 2008). A surplus of ROS and the absence of optimal amounts of antioxidants are leading to oxidative stress (Lykkesfeldt and Svendsen, 2007). Progressive development of oxidative stress in periparturient dairy cows is a significant underlying factor leading to dysfunctional inflammatory responses (Sordillo and Aitken 2009; Osorio et al., 2014). Alterations in haemato-biochemical parameters have been correlated to aid diagnosis as well as treatment. Recent pathophysiological studies suggest that management of oxidative stress has a significant role in combating bovine mastitis and its recurrence and incidence. During lactation, mammary epithelial cells exhibit a high metabolic rate and thus produce large amounts of reactive oxygen species and lipid peroxides in vivo (Jin et al., 2014; Ganguly et al., 2016). Increased reactive oxygen species level or decreased antioxidants can disrupt the balance between oxidants and antioxidants which is referred to as oxidative stress (Sordillo et al., 2009). This create a more oxidizing environment that facilitate the binding of pathogens or antigens to effector cells leading to a hyper-responsive innate immune system and enhanced production of cytokines (Maddox et al., 1999). Reactive oxygen species can oxidize macromolecules such as lipids, proteins and DNA and cause direct oxidative cell injury or indirectly can modify metabolic pathways (Miller et al., 1993). Lipid peroxidation in clinical mastitis reduces the levels of some antioxidant molecules leading to an increase in the oxidative stress state (Weiss et al., 2004). Mastitis could induce the increase of free radicals formation in milk and leading to oxidative stress (Gu et al., 2009), especially during the early lactation period of dairy cows (Sordillo et al., 2007). Both CM and SCM are associated with release of free radicals, increased total oxidant capacity and decreased total antioxidants capacity in milk (Atakisi $e t$ al., 2010; Patnaik et al., 2014). It has been reported that significant decrease in blood superoxide dismutase (SOD) and catalase activities, reduced glutathione (GSH) concentration and an increase in erythrocytic lipid peroxides was observed in cows with clinical mastitis (Jhambh et al., 2013). The literature on oxidative stress in buffalo mastitis is scanty. Therefore, the present study was carried out to study the oxidative stress aspects of mastitis in cattle. This study has been undertaken to study the changes in the activities of erythrocyte glutathione peroxidase (GSH-Px) with its functional component and also to compare the activities of erythrocyte superoxide dismutase (SOD) with functional components in cows with subclinical mastitis and normal cows of 
Odisha. Also, the study was undertaken on the therapeutic efficacy for antioxidants along with the antibiotics on restoration of changes in oxidative stress indices.

\section{Materials and Methods}

\section{Study design}

60 mastitis cattle were selected for experimental study and divided into three groups of 20 animals in each, namely Group I, II and III. Another 20 cattle reared in the locality of Bhubaneswar, without any overt clinical signs of any disease, apparently healthy and negative for mastitis were taken as healthy control group (Group IV).The therapeutic regimen of the Group I and II were followed as per the following experimental protocol as stated in the Table 1.

In groups I, II and III, twenty cattle clinically affected with clinical mastitis (CM) were treated with Marbofloxacin (Marbodac) as parenteral antibiotic through intra muscular route, repeated after 3 days for two doses at the dose rate of $8 \mathrm{mg} / \mathrm{kg}$ body weight along with intramammary infusion of Cefoperazone (Mammicef) at the dose rate of 1 syringe per affected quarter. In group II, animals were also administered with anti-oxidants namely Vitamin-E and Selenium (Repronol) as supportive therapy through intra muscular route, at weekly interval for four doses at the dose rate of $1 \mathrm{ml} / 30 \mathrm{~kg}$ body weight. However, in group-III animals were administered with anti-oxidants namely Vitamin-C (Livocef 25\%) and Selenium (Repronol) as supportive therapy through intra muscular route, at weekly interval for four doses at the dose rate of $1 \mathrm{ml} / 30 \mathrm{~kg}$ body weight. In group-IV twenty cattle reared in the locality of Bhubaneswar, sharing a similar environment and climatic conditions as mentioned above were taken healthy control. These animals were without clinical signs of any disease and negative for bovine mastitis through PH, SCC, EC and MCMT examination. They were monitored for clinical sign of any disease during the study period and thus given no treatment. All the animal procedures were performed according to the guidelines of the Animal Ethics Committee of College of Veterinary Science and Animal Husbandry, OUAT, Bhubaneswar.

\section{Collection of blood samples}

The blood samples of the selected 20 cattle for the present experiment was collected in heparinised vials on day 0, day 14 and day 28 i.e. before, during and after treatment for estimation of oxidative indices.

\section{Measurement of therapeutic efficacy}

The response to treatment was evaluated on the basis of milk characteristics (SCC, EC, $\mathrm{pH}$ ) and the time taken for recovery. EC and $\mathrm{pH}$ was determined by digital $\mathrm{pH}$ meter.

\section{Estimation of erythrocytic oxidative indices}

\section{Estimation of lipid peroxidation}

It was determined as per placer et al., (1966). Briefly, to $0.2 \mathrm{ml}$ haemolysate in a test tube, $1.3 \mathrm{ml}$ Tris-KCl buffer was added and incubated for 30 minute at $37^{\circ} \mathrm{C}$ temperature. Then to this $1.5 \mathrm{ml}$ TBA reagent was added and heated in boiling water bath for 10 minute with marble as a condenser. The tube was cooled under tap water and $3 \mathrm{ml}$ pyridinebutanol mixture was added followed by $1 \mathrm{ml}$ IN $\mathrm{NaOH}$ and mixed well. A blank was run containing $0.2 \mathrm{ml}$ distill water in place of haemolysate. Then absorbance was measured @ 548 nm against blank.

Taking E548 Molar extinction coefficient of MDA-TBA complex @ $548 \mathrm{~nm}$ is used, it is $1.56 \times 108 / \mathrm{M} / \mathrm{cm}$ of path. 
MDA $(\mathrm{m} / \mathrm{g} \mathrm{Hb})=\left(\mathrm{OD}\right.$ of test $\left./ \mathrm{E}_{548}\right) \times(7 / 0.2) \times$ $5 \times 100 \times 10^{6} / \mathrm{Hb}(\mathrm{g} \%)$ in haemolysate or (mmol/mg Hb)

(7 - Final volume of mixture, 0.2 - Volume of hemolysate taken, 100 - To convert per ml volume to $100 \mathrm{ml}$ volume to bring it into same unit as $\mathrm{Hb}$.)

\section{Estimation of catalase}

It is based on degradation of $\mathrm{H} 2 \mathrm{O} 2$ by catalase as per the method described by Cohen, et al., 1970. Here $2.9 \mathrm{ml}$ of $\mathrm{H} 2 \mathrm{O} 2$ solution was taken into cuvette directly to which $0.1 \mathrm{ml}$ of haemolysate solution was added and mixed immediately by inversion /plastic paddle. O.D. was recorded at $240 \mathrm{~nm}$ by using double beam spectrophotometer. Time required for the Abs240 nm to decrease from 0.45 to 0.40 was noted. Reading is taken against phosphate buffer as blank.

Units/g Hb in hemolysate $=3.45 \times 100 / \mathrm{T} \mathrm{x}$ $0.1 \times \mathrm{Hb}$ (g \% of haemolysate)

$\mathrm{T}=$ Time in minute required for the Abs240, to decrease from 0.45- 0.40 Absorbance unit

\section{Estimation of superoxide dismutase (SOD)}

SOD was estimated as per Marklund and Marklund (1974) with little modification as per Masayasu Hiroshi, 1979). SOD activity of RBC haemolysate samples can be measured using nitro blue tetrazolium as a substrate.

The reaction was carried out in a total volume of $3 \mathrm{ml}$ consisted of $50 \mathrm{mM}$ of Tris-cacodylic acid buffer $\mathrm{Ph}$ 8.2, Enzyme preparation after suitable dilution of sample and $0.2 \mathrm{mM}$ of pyrogallol. In the blank enzyme was substituted by equal quantity of distilled water. The increase in absorbance due to auto oxidation of pyrogallol was recorded at $420 \mathrm{~nm}$ using spectrophotometer.

\section{Calculation}

One unit of SOD activity was defined as the amount of enzyme which inhibited the pyrogallol auto oxidation by $50 \%$ under the given experimental condition. The values were expressed as units/ $\mathrm{mg}$ of haemolgobin or protein.

SOD $($ units $/ \mathrm{mg})=(\mathrm{OD}$ of Blank-OD of Test $) /$ OD OF Blank 100/ 50 Dilution factor $\mathrm{Mg}$ of $\mathrm{Hb}$ in Haemolysate.

\section{Statistical analysis}

All the data generated in the above experiments were statistically analyzed using SPSS (1996) computer package. For comparison of groups, Generalized Linear Model, ANOVA procedure and were used (Steel and Torrie, 1980).

\section{Results and Discussion}

\section{Comparative efficacy of different therapeutic regimes in the treatment of acute bovine clinical mastitis}

20 animals each in 3 groups evaluated for recovery rate after 3 days and 5 days based on milk pH, SCC and EC. The present study revealed there is significant difference of group $2(\mathrm{p}=0.05)$ than group 1 , group 3 in recovery rate after 3 days. Similarly group 2 is significantly differs from group 1 in term of recovery rate after 5 days. The mean recovery \pm S.E. time (days) of group 1, group 2 , group 3 are 7, 6, 5 respectively. From the present study it revealed that group 2 which was supplemented with vit-E and selenium along with antibiotics showed better recovery rate in day 3 and day 5 and also recorded a very less mean recovery time. The comparative efficacy of each treatment regime in the recovery of clinical mastitis is given in Table 1 . The recovery was established on the 
basis of clinical presentation and changes in milk characteristics (Table 2).

\section{Erythrocytic oxidative indices}

The erythrocytic oxidative enzymes of all the 60 animals of the three groups were studied by collection of blood samples on day 0 , day 15 and day 30 of the experiment. The different oxidative enzymes studied were lipid peroxidase (LPO), super oxide dismutase (SOD) and catalase.

\section{Mean erythrocytic lipid peroxidase (LPO)}

The mean erythrocytic lipid peroxidase (LPO) in cattle of different experimental groups at different observation periods is given in Table
3. On day 0 , the mean erythrocytic lipid peroxidase concentration in cattle in group I (4.77 \pm 0.15$)$, group II $(4.76 \pm 0.19)$ and in group III $(4.78 \pm 0.13)$ were at significantly higher level $(\mathrm{p}<0.05)$ as compared to healthy control group IV $(1.13 \pm 0.04)$. Significant $(p<0.05)$ decrease in the mean erythrocytic lipid peroxidase level in group I (3.24 \pm 0.07$)$, group II (1.91 \pm 0.08$)$ and group III $(2.93 \pm 0.11)$ were found on day 15 as compared to their day 0 . Significant $(p<0.05)$ decrease in the mean erythrocytic LPO level of both group I $(2.04 \pm 0.06)$, group II $(1.01 \pm 0.04)$ and group III $(1.74 \pm 0.08)$ were found on day 30 as compared to their day 15 . On day 30 only group II has non significantly differ with healthy control group suggesting better relief from oxidative stress (Table 3).

\section{Experimental protocol}

\begin{tabular}{|c|c|c|c|c|}
\hline S.No. & Group & No of animals & Clinical condition & Treatment \\
\hline 1 & I & 20 & Clinical mastitis & $\begin{array}{l}\text { 1. Inj. Marbofloxacin }\left(\text { Marbodac }^{\mathrm{R}}\right) @ \\
8 \mathrm{mg} / \mathrm{kg} \text { b.wt. }(\mathrm{I} / \mathrm{m} 2 \text { doses repeated after } \\
3 \text { days) } \\
\left.\text { 2. Imf. Cefoperazone (Mammicef }{ }^{\mathrm{R}}\right) @ \\
\text { one syringe per affected quarter. }\end{array}$ \\
\hline 2 & II & 20 & Clinical mastitis & $\begin{array}{l}\text { Inj. Marbofloxacin }\left(\text { Marbodac }^{\mathrm{R}}\right) @ \\
\text { 8mg/kg bwt (I/M } 2 \text { doses repeated after } 3 \\
\text { days) } \\
\left.\text { Imf. Cefoperazone (Mammicef }{ }^{\mathrm{R}}\right) @ \text { one } \\
\text { syringe per affected quarter. } \\
\text { Vitamin-E and Selenium (Repronol) } \\
@ 1 \mathrm{ml} / 50 \mathrm{~kg} \text { b.wt. weekly once }\end{array}$ \\
\hline 3 & III & 20 & Clinical mastitis & $\begin{array}{l}\text { 1. Inj. Marbofloxacin }\left(\text { Marbodac }^{\mathrm{R}}\right) \text { @ } \\
\text { 8mg/kg bwt (I/M } 2 \text { doses repeated after } 3 \\
\text { days) } \\
\left.\text { 2. Imf. Cefoperazone (Mammicef }{ }^{\mathrm{R}}\right) @ \\
\text { one syringe per affected quarter. } \\
\left.\text { 3. Vitamin-C(Livocef }{ }^{\mathrm{R}}\right) @ 25 \mathrm{mg} / \mathrm{kg} \\
\text { b.wt. weekly once }\end{array}$ \\
\hline 4 & IV & 20 & Healthy control & No treatment \\
\hline
\end{tabular}


Table.1 Comparative efficacy of different therapeutic regimes in the treatment of acute bovine clinical mastitis

\begin{tabular}{|l|l|l|l|}
$\begin{array}{l}\text { Treatment } \\
\text { group }\end{array}$ & $\begin{array}{l}\text { Recovery rate } \\
\text { after } \mathbf{3} \text { day }\end{array}$ & $\begin{array}{l}\text { Recovery rate } \\
\text { after 5 day }\end{array}$ & $\begin{array}{l}\text { Mean recovery } \pm \\
\text { S.E. time(days) }\end{array}$ \\
\hline GROUP I & $40 \%(8 / 20)^{\mathrm{a}}$ & $60 \%(12 / 20)^{\mathrm{a}}$ & 7 \\
\hline GROUP II & $75 \%(15 / 20)^{\mathrm{b}}$ & $90 \%(18 / 20)^{\mathrm{b}}$ & 6 \\
\hline GROUP III & $50 \%(10 / 20)^{\mathrm{a}}$ & $75 \%(15 / 20)^{\mathrm{ab}}$ & 5 \\
\hline
\end{tabular}

Table.2 Effect of treatment on milk chemistry in bovine mastitis (mean \pm S.E.)

\begin{tabular}{|l|l|l|l|l|l|l|}
\hline \multirow{2}{*}{ Parameter } & \multicolumn{2}{|c|}{ Group I } & \multicolumn{2}{c|}{ Group II } & \multicolumn{2}{c|}{ Group III } \\
& Pre treated & Post treated & Pre treated & Post treated & Pre treated & Post treated \\
\hline pH & $7.2 \pm 0.024$ & $6.7 \pm 0.031$ & $7.2 \pm 0.032$ & $6.7 \pm 0.025$ & $7.2 \pm 0.027$ & $6.7 \pm 0.031$ \\
\hline EC(ms/cm) & $6.5 \pm 0.32$ & $4.2 \pm 0.032$ & $6.6 \pm 0.19$ & $4.2 \pm 0.041$ & $6.5 \pm 0.44$ & $4.2 \pm 0.029$ \\
\hline SCC x 10 & $8.64 \pm 0.65$ & $2.75 \pm 0.21$ & $8.72 \pm 0.53$ & $2.17 \pm 0.21$ & $8.69 \pm 0.41$ & $1.68 \pm 0.16$ \\
\hline
\end{tabular}

Table.3 Mean erythrocytic lipid peroxide (LPO) (nmol/mg Hb)

\begin{tabular}{|c|c|c|c|c|}
\hline S.No. & Group & Day 0 & Day 15 & Day 30 \\
\hline $\mathbf{1}$ & I & $4.77 \pm 0.15^{\mathrm{bC}}$ & $3.24 \pm 0.07^{\mathrm{cB}}$ & $2.04 \pm 0.06^{\mathrm{bA}}$ \\
\hline $\mathbf{2}$ & II & $4.76 \pm 0.19^{\mathrm{bC}}$ & $1.91 \pm 0.08^{\mathrm{bB}}$ & $1.01 \pm 0.04^{\mathrm{aA}}$ \\
\hline $\mathbf{3}$ & III & $4.78 \pm 0.13^{\mathrm{bC}}$ & $2.93 \pm 0.11^{\mathrm{cB}}$ & $1.74 \pm 0.08^{\mathrm{bA}}$ \\
\hline $\mathbf{4}$ & IV & $1.13 \pm 0.04^{\mathrm{a}}$ & $1.14 \pm 0.06^{\mathrm{a}}$ & $1.14 \pm 0.03^{\mathrm{a}}$ \\
\hline
\end{tabular}

*Values are expressed as Mean \pm S.E. values. Parenthesis denotes range. Mean values with different superscripts (A, $\mathrm{B} \& \mathrm{C}$ ) differs in a row significantly within a group at $\mathrm{P} \leq 0.05$ and superscripts $(\mathrm{a}, \mathrm{b} \& \mathrm{c}$ ) differs in a column between the groups significantly at $\mathrm{P} \leq 0.05$.

Table.4 Mean erythrocytic super oxide dismutase (SOD) (units/mg Hb)

\begin{tabular}{|c|c|l|l|l|}
\hline S.No. & Group & Day 0 & Day 15 & Day 30 \\
\hline $\mathbf{1}$ & I & $1.86 \pm 0.13^{\mathrm{aa}}$ & $2.56 \pm 0.17^{\mathrm{ab}}$ & $2.91 \pm 0.16^{\mathrm{ab}}$ \\
\hline $\mathbf{2}$ & II & $1.85 \pm 0.11^{\mathrm{aa}}$ & $2.94 \pm 0.21^{\mathrm{ab}}$ & $4.14 \pm 0.29^{\mathrm{bc}}$ \\
\hline $\mathbf{3}$ & III & $1.84 \pm 0.17^{\mathrm{aa}}$ & $2.66 \pm 0.19^{\mathrm{ab}}$ & $3.12 \pm 0.11^{\mathrm{ab}}$ \\
\hline $\mathbf{4}$ & IV & $4.04 \pm 0.14^{\mathrm{b}}$ & $4.06 \pm 0.17^{\mathrm{b}}$ & $4.01 \pm 0.16^{\mathrm{b}}$ \\
\hline
\end{tabular}

Table.5 Mean erythrocytic catalase (units/mg $\mathrm{Hb}$ )

\begin{tabular}{|c|c|c|l|l|}
\hline S.No. & Group & Day 0 & Day 15 & Day 30 \\
\hline $\mathbf{1}$ & I & $1.47 \pm 0.13^{\mathrm{aa}}$ & $1.82 \pm 0.14^{\mathrm{ab}}$ & $2.02 \pm 0.16^{\mathrm{ab}}$ \\
\hline $\mathbf{2}$ & II & $1.49 \pm 0.11^{\mathrm{aa}}$ & $2.08 \pm 0.11^{\mathrm{b}}$ & $2.70 \pm 0.18^{\mathrm{bc}}$ \\
\hline $\mathbf{3}$ & III & $1.50 \pm 0.08^{\mathrm{aa}}$ & $1.96 \pm 0.17^{\mathrm{b}}$ & $2.09 \pm 0.11^{\mathrm{ab}}$ \\
\hline $\mathbf{4}$ & IV & $2.13 \pm 0.06^{\mathrm{b}}$ & $2.10 \pm 0.08$ & $2.07 \pm 0.12^{\mathrm{a}}$ \\
\hline
\end{tabular}




\section{Mean erythrocytic super oxide dismutase} (SOD)

The mean erythrocyticsuper oxide dismutase (SOD) in cattle of different experimental groups at different observation periods is represented in Table 4. Mastitis affected cattle revealed significantly $(\mathrm{p}<0.05)$ lower level of mean erythrocytic super oxide dismutase on day 0 in group I $(1.86 \pm 0.13)$, group II $(1.85 \pm 0.11)$ and group III $(1.84 \pm 0.17)$ as compared to healthy control group III $(4.04 \pm 0.14)$. Significant $(\mathrm{p}<0.05)$ increase in the mean erythrocytic super oxide dismutase level of both group I $(2.56 \pm 0.17)$, group II $(2.94 \pm 0.21)$ and group III $(2.66 \pm 0.19)$ was found on day 15 as compared to their day 0 . On day 15 the level of SOD in group I, II\&III were at a significantly lower level than group IV. On day 30, significant $(\mathrm{p}<0.05)$ increase in the mean erythrocytic SOD level of group II (4.14 \pm 0.29$)$, and group III ( $3.12 \pm 0.11)$ were found with respect to its day 15 whereas in group I (2.91 \pm 0.16$)$ there was increase in SOD level at a non-significant higher level.

\section{Mean erythrocytic catalase}

The mean erythrocytic catalase level in cattle of different experimental groups at different observation periods is given in Table 5 . Mastitis affected cattle revealed significantly $(p<0.05)$ lower level of mean erythrocytic catalase on day 0 in group I $(1.47 \pm 0.13)$, group II $(1.49 \pm 0.11)$ and in group III $(1.50 \pm 0.08)$ as compared to healthy control group IV $(2.13 \pm 0.06)$. Significant $(\mathrm{p}<0.05)$ increase in the mean erythrocytic catalase level of group II $(2.08 \pm 0.11)$ was found on day 15 as compared to their day 0 , but the increase in catalase level in group I $(1.82 \pm 0.14)$ was at a non-significantly higher level with respect to its day 0. However on day 30 , the mean erythrocytic catalase level of group II (2.70 \pm 0.18$)$ was found to be at a significantly higher level than in group I whereas there was increase in catalase value at a statistically non-significant level in group I $(2.02 \pm 0.16)$ with respect to its day 15 value.

Mastitis is one of the important disease entities that create hindrance in the development process of dairy industry. Oxidative stress occurs when the production of reactive oxygen metabolites (ROM) exceeds the capacity of the antioxidant system of the cell, tissue or body. Certain nutrients act as antioxidants and are components of antioxidant enzymes and have a direct effect on oxidative stress. Both water and fat soluble antioxidants are needed because free radicals are found in both areas of cells. Vitamin E and selenium has been shown to reduce prevalence and severity of mastitis and reduce SCC (Smith et al., 1997; Weiss et al., 1997). Selenium and vitamin E act in an apparently synergistic way to protect the mammary gland.

There is increased phagocytic activity when vitamin $\mathrm{E}$ was provided with antibiotics in clinical mastitis (Mukherjee, 2007). In this study, antioxidant supplementation like Vit-E and $\mathrm{Se}$ or Vit-C along with antibiotics increased the recovery rate and decreased the mean recovery time in treatment of bovine mastitis Ascorbic acid (vitamin C) has multidimensional bioactive role in the body system, the most important being that of an antioxidant, antibacterial activity and maintenance of optimum immune responses. The polymorphonuclear cell (PMN) migration and its lysosomal antioxidant enzyme, mycloperoxidase (MPO) synthesis is largely dependent on ascorbates. The antioxidant role of ascorbates is to neutralize the toxic peroxides and other reactive oxygen species (ROS) released during cellular activation due to bacterial infection, which cause tissue injury. Singh and Pachauri (2003) observed a significant decrease of ascorbic acid in milk and blood of both subclinical and clinical 
cases of mastitis and suggested its supplementation during the disease

From the present study, it may be concluded that ascorbic acid therapy is of potential benefits, particularly when used concurrently with antibacterial formulation in order to modulate udder immunity, prevent mammary tissue from noxious insult of toxic lipid peroxidases and also potentiate antimicrobial activity of antibacterial drugs. In conclusion, a therapeutic trial was conducted on cases of acute bovine mastitis. In conclusion, Marbofloxacin@8mg/kg body weight (I/M) and cefoperazone intramammary infusion along with vitamin $\mathrm{E}$ and Selenium was proved as an effective therapy against acute bovine clinical mastitis.

\section{References}

Atakisi, O., Oral, H., Atakisi, E., Merhan, O., Pancarci, S.M., Ozcana, A., Marasli, S., Polat, B., Colak, A. and Kaya, S. 2010. Subclinical mastitis causes alterations in nitric oxide, total oxidant and antioxidant capacity in cow milk. Research in Veterinary Science, 89: 1013.

Bhanderi, B.M. and Garg, M.R. 2012. A study on reducing the incidence of subclinical in dairy cows by feeding a vitamins and minerals based strategic feed supplement. Indian Journal of Dairy Science, 65(5): 388-392.

Blum, J.W., Dosogne, H., Hoeben, D., Vangroenweghe, F., Hammon, H. M., Bruckmaier, R. M., and Burvenich, C. 2000. Tumor necrosis factor- $\alpha$ and nitrite/nitrate responses during acute mastitis induced by Escherichia coli infection and endotoxin in dairy cows. Domestic Animal Endocrinology, 19(4), 223-235.

Bouchard, L., Blais, S., Desrosiers, C., Zhao, X., and Lacasse, P. 1999. Nitric Oxide
Production During Endotoxin-Induced Mastitis in the Cow1. Journal of Dairy Science, 82(12), 2574-2581.

Cohen, G., Kim, M. and Ogwu, V. 1996. A modified catalase assay suitable for a plate reader and for the analysis of brain cell cultures. Journal of Neuroscience Methods, 67(1), 53-56.

Ganguly, S., Padhy, A., Sahoo, S., Garg, S.L., Wakchaure, R., Praveen, P.K., Para, P.A., Mahajan, T., Qadri, K. and Sharma, R. 2016. Antibiogram of milk sample of a farm maintained dairy cow suffering from mastitis followed by its clinical recovery. Int. J. Sci. Environ. Technol. 5(1): 148-151.

Gu, B., Zhu, Y., Zhu, W., Miao, J., Deng, Y. E. and Zou, S. 2009. Retinoid protects rats against neutrophil-induced oxidative stress in acute experimental mastitis. Int. Immunopharmacol., 9(2): 223-229.

Jhambh, R., Dimri, U., Gupta, V.K. and Rathore, R. 2013. Blood antioxidant profile and lipid peroxides in dairy cows with clinical mastitis. Veterinary World, 6: 271-273.

Jin, L., Yan, S.M., Shi, B.L., Bao, H.Y., Gong, J., Guo, X.Y. and Li, J.L. 2014. Effects of vitamin A on the milk performance, antioxidant functions and immune functions of dairy cows. Animal Feed Science and Technology, 192: $15-23$.

Jozwik A., Strzałkowska N., Bagnicka E., Grzybek W., Krzyzewski J., Poławska E., Kolataj A. and Horbańczuk J.O. 2012b. Relationship between milk yield, stage of lactation and some blood serum metabolic parameters of dairy cows. Czech Journal of Animal Science, 57 (8): 353-360.

Komine, K., Kuroishi, T., Komine, Y., Watanabe, K., Kobayashi, J., Yamaguchi, T., Kamata, S. and Kumagai, K., 2004. Induction of nitric 
oxide production mediated by tumor necrosis factor alpha on staphylococcal enterotoxin C-stimulated bovine mammary gland cells. Clinical Diagnosis in Laboratory Immunology, 11: 203-210.

Lykkesfeldt, J. and Svendsen, O. 2007. Oxidants and antioxidants in disease: oxidative stress in farm animals. The Veterinary Journal, 173: 502-511

Maddox, J.F., Aherne, K.M., Reddy, C.C., and Sordillo, L. M. 1999. Increased neutrophil adherence and adhesion molecule mRNA expression in endothelial cells during selenium deficiency. Journal of Leukocyte Biology, 65(5), 658-664.

Marklund, S. and Marklund, G. 1974. Involvement of the superoxide anion radical in the autoxidation of pyrogallol and a convenient assay for superoxide dismutase. The FEBS Journal, 47(3): 469-474.

Masayasu, M., and Hiroshi, Y. 1979. A simplified assay method of superoxide dismutase activity for clinical use. Clinica Chimica Acta, 92(3), 337-342.

Miller, J.K., Brzezinska-Slebodzinska, E., and Madsen, F.C. 1993. Oxidative stress, antioxidants, and animal function. Journal of Dairy Science, 76(9), 28122823.

Mukherjee, R. 2007. Effect of bovine recombinant somatotropin on the occurrence of clinical mastitis in lactating buffaloes. Indian Journal of Veterinary Medicine, 27(1), 60.

Osorio, J. S., Trevisi, E., Ji, P., Drackley, J. K., Luchini, D., Bertoni, G. and Loor, J.J. 2014. Biomarkers of inflammation, metabolism, and oxidative stress in blood, liver, and milk reveal a better immunometabolic status in peripartal cows supplemented with smartamine $m$ or metasmart. J. Dairy Sci., 97(12): 7437-7450.
Patnaik, S., Prasad, A. and Ganguly, S. 2014. Biochemical characterization and antibiogram of Staphylococcal microorganisms associated with subclinical mastitis in lactating crossbred cows. Animal Science Reporter, 8(4): 123-129.

Placer, Z.A., Cushman, L.L. and Johnson, B.C. 1966. Estimation of product of lipid peroxidation (malonyl dialdehyde) in biochemical systems. Analytical Biochemistry, 16(2), 359-364.

Pyorala, S. 2003. Indicators of inflammation in the diagnosis of mastitis. Vet. Res., 34(5):565-578.

Radostits, O.M., Gay, C.G., Hinehcliff, K.W. and Blood, D.C. 2010. Veterinary Medicines. A Textbook of the Diseases of Cattle, Sheep, Pigs, Goats, and Horses. $9^{\text {th }}$ ed., Page 611. W.B. Saunder's Publication Kent, China.

Radostits, O.M., Gay, C.C., Hinchcliff, K.W. and Constable, P.D. 2007. Veterinary Medicine, 10. Edition. Saunders Elsevier, Philadelphia, USA. Pp. 673748.

Rinaldi, M., Moroni, P., Paape, M. J., and Bannerman, D. D. 2008. Differential alterations in the ability of bovine neutrophils to generate extracellular and intracellular reactive oxygen species during the periparturient period. The Veterinary Journal, 178(2): 208-213.

Singh, S. V. and Pachauri, S. P. (2003) Indian J. Vet. Med., 23: 88-89.

Smith, K.L., Hogan, J.S. and Weiss, W.P. 1997. Dietary vitamin E and selenium affect mastitis and milk quality. Journal of Animal Science, 75(6): 1659-1665.

Sordillo, L.M. 2009. Current concepts on immunity and mastitis. WCDS Advances in Dairy Technology, 21: 111119.

Sordillo, L.M. and Aitken, S.L. 2009. Impact of oxidative stress on the health and immune function of dairy cattle. Vet. 
Immunol. Immunopathol., 128(1-3): 104-109.

Sordillo, L.M., O'Boyle, N., Gandy, J.C., Corl, C.M. and Hamilton, E. 2007. Shifts in thioredoxin reductase activity and oxidant status in mononuclear cells obtained from transition dairy cattle. Journal of Dairy Science, 90: 11861192.

Steel, R. G. and Torrie, J.H. 1980. Principle and procedures of statistic: A biometrical approach.

Wakchaure, R., Ganguly, S., Para, P.A., Praveen, P.K. and Qadri, K. 2015. Mastitis, an economically important disease affecting lactating ruminants: A Review. Chap. 15, pp. 199-212. In: New Dimensions in Microbiology [Eds. Dr.
M.M. Abid Ali Khan (India), Dr. John K. Grandy (USA), Dr. Egamberdieva Dilfuza (Germany), Murataza Abid (India), Dr. Raaz K. Maheshwari (India), Dr. T.S. Naqvi (India). Lenin Media Pvt. Ltd., Delhi, India.

Weiss, W. 2002. Relationship of mineral and vitamin supplementation with mastitis and milk quality. In: Annual MeetingNational Mastitis Council Inc. (Vol. 41, pp. 37-44). National Mastitis Council.

Weiss, W.P., Hogan, J.S., Smith, K.L. 2004. Changes in vitamin $\mathrm{C}$ concentrations in plasma and milk from dairy cows after an intramammary infusion of Escherichia coli. Journal of Dairy Science, 87: 32-37.

\section{How to cite this article:}

Anshuman Mahapatra, Sumitra Panigrahi, Ramesh C. Patra, Mangalika Rout and Subha Ganguly. 2018. A Study on Bovine Mastitis Related Oxidative Stress along with Therapeutic Regimen. Int.J.Curr.Microbiol.App.Sci. 7(01): 247-256. doi: https://doi.org/10.20546/ijcmas.2018.701.027 